4 Zarski JP, Aubert H, Rachail M. Toxicité hépatique des nouveaux antidépresseurs. A propos d'une observation. Gastroentérol Clin Biol 1983;7:220-1.

5 Larrey D, Rueff B, Pessayre D, et al. Cross hepatotoxicity between tricyclic antidepressants. Gut 1986;27:726-7.

(Accepted 24 April 1987)

Service d'Hépato-Gastroentérologie and Unité de Pharmacologie Clinique,

Centre Hospitalier Universitaire, 80030 Amiens Cedex, France.

M ANDREJAK, MD, professor of medicine

T DAVION, MD, intern

J L GINESTON, MD, hospital practitioner

J P CAPRON, MD, professor of medicine

Correspondence to: Dr Capron.

\section{Management of blisters in minor burns}

The best way to manage blisters in minor burns is controversial. Recommended procedures include deroofing, ${ }^{12}$ aspiration, ${ }^{3}$ and leaving blisters intact. ${ }^{4}$ The choice of treatment is usually based on clinical impression and experience. We investigated the effects of these three treatments on bacterial colonisation of the blister fluid or surface of the burn and on wound pain in patients with minor burns.

\section{Methods and results}

Altogether 202 patients attending two accident departments for treatment of minor burns were included in the investigation. The extent of injury averaged $1 \%$ of body surface area; all burns except one were partial thickness and healed with conservative treatment. Only thermal burns of the arms and legs that could be treated with paraffin gauze dressings were included; most were of mixed depth All residual sprays and ointments used in first aid were removed by washing with sterile saline. The patients were asked to attend the next weekday burns clinic and were seen thereafter two or three times a week for dressings.

During the first part of the study blisters were left intact for up to 10 days to determine the risk of colonisation or infection of blister fluid; fluid was aspirated through a single puncture hole. In the second part blister fluid was aspirated through a single puncture hole at the first follow up visit and the blister dressed. The lumen of the blister was swabbed once during the next 12 days. Throughout the investigation exposed tissue burns were swabbed once up to 12 days after injury. Sampling times were comparable in aspirated and exposed burns. The sample of fluid (intact burns) and swab (aspirated and exposed burns) were analysed according to standard bacteriological methods. Some of the blisters which were aspirated in the second part of the study were actively deroofed. Patients whose blisters were aspirated or deroofed were asked at least one day later whether the pain in the burnt area had increased, decreased, or remained unchanged after treatment. Differences were assessed by $\chi^{2}$ tests.

Effect of different treatments on bacterial colonisation

\begin{tabular}{lccc}
\hline & \multicolumn{3}{c}{ Blister treatment } \\
\cline { 2 - 4 } & $\begin{array}{c}\text { Intact } \\
(\mathrm{n}=110)\end{array}$ & $\begin{array}{c}\text { Aspirated } \\
(\mathrm{n}=104)\end{array}$ & $\begin{array}{c}\text { Exposed } \\
(\mathrm{n}=102)\end{array}$ \\
\hline No (\%) colonised any bacterium & $\begin{array}{c}15(14) \\
2(2)\end{array}$ & $\begin{array}{c}73(70) \\
19(18)\end{array}$ & $\begin{array}{c}78(76) \\
45(44)\end{array}$ \\
\hline
\end{tabular}

The table records the incidence of colonisation in the three study groups. The overall incidence of colonisation with micro-organisms was much lower in the intact blisters than in either the aspirated blisters or the exposed tissue burns $(p<0.05)$. The incidence of infection with the potential pathogen Staphylococcus aureus was significantly lower in both the intact and aspirated blisters compared with the exposed burns $(p<0 \cdot 05)$. Furthermore, aspiration and deroofing had a different effect on the patients' perception of wound pain. None of the 37 patients whose blisters were deroofed experienced a reduction in pain (in 16 pain increased and in 21 it was unchanged), but aspiration reduced pain in 27 out of 73 patients (15 increased, 36 unchanged). This difference was significant $(p<0 \cdot 05)$.

\section{Comment}

Our results show that an intact blister roof prevents colonisation of minor burns by bacteria, especially Staph aureus. This conclusion supports the findings of Cope, who observed infected fluid in only one intact blister in 26 patients (Streptococcus pyogenes). The importance of colonisation of small burn wounds in terms of morbidity and healing is unknown, but colonisation should be minimised. Infection is a severe problem with major burn injuries, and the portal of entry of the organisms is probably the burn wound.

Our results suggest that in minor burns blisters should be left intact whenever possible and not be deroofed if they rupture spontaneously. Deroofing is likely to lead to more pain and an exposed surface is associated with a higher incidence of colonisation with Staph aureus. Obviously these findings should not dictate an inflexible policy toward treatment. Many blisters will spontaneously rupture and deroof. If blisters are to be drained because of their size or site aspiration is preferable to deroofing, which is warranted only when infection is clinically evident.

1 Hummel RP. Initial wound management. In: Hummel RP, ed. Clinical burn therapy. Boston: John Wright, 1982.87-110.

2 Muir IFK, Barclay TL. Local treatment of the burn wound. In: Muir IFK, Barclay TL, eds. Burns and their treatment. London: Lloyd-Luke, 1974: 68-9.

3 Bruck M. The management of small burns. In: Artz CP, Moncrief JA, Pruitt BA, eds. Burns-a team approach. Philadelphia: W B Saunders, 1979: 165-8.

4 Lewis SR, Lynch JB, Blocker TG, et al. Evaluation of topical burn therapy over the past 20 years. In: Matter P, Barclay TL, Konickova Z, eds. Transactions of the 3rd international congress on research in burns. Berne: Hans Huber, 1971: 108-11.

5 Cope O. The treatment of surface burns. Ann Surg 1943; 117: 885-93.

(Accepted 24 April 1987)

St Richard's Hospital, Chichester PO19 4SE and Charing Cross Hospital, London W6 8RF

ANDREW H SWAIN, PHD, FRCS, senior registrar, accident and emergency medicine

\section{Charing Cross Hospital, London W6 8RF}

BERGE S AZADIAN, BSC, MRCPATH, consultant clinical microbiologist

CHARLES J WAKELEY, BSC, MB, senior house officer, accident and emergency medicine

\section{Odstock Hospital, Salisbury SP5 3LE}

PETER G SHAKESPEARE, BSC, PHD, director, Laing laboratory

Correspondence to: Mr A H Swain, Accident and Emergency Department, Worcester Royal Infirmary, Worcester WR1 3AS.

\section{Cervical cytology screening: a comparison of two call systems}

A study was undertaken to investigate two methods of call up as part of the pilot scheme for the Nottingham cervical cytology programme, in which the health authority and the family practitioner committee are collaborating. There is a consensus that such programmes should closely involve general practitioners and that encouragement from them achieves high rates of response. ${ }^{12}$ This study was designed to discover whether a letter of invitation from the general practitioner to women with no record of having had a cervical smear test would be more effective if it contained a definite date and time for a smear test than if it just invited the woman to contact the surgery and make her own arrangements.

\section{Patients, methods, and results}

Five general practices, which did not have an established programme, agreed to participate in the project. They comprised four two doctor and one four doctor partnerships and represented a reasonable geographical spread within the authority from inner city to suburban. Women aged 45-65 were identified from the register of the family practitioner committee. There were 2264 women in the five practices. Notes were available for 2174 , and of these $906(42 \%)$ had no record of having had a cervical smear. The general practitioners were asked to exclude any women they did not wish to call for a smear; 68 were excluded, most because of hysterectomy but some because of other medical conditions.

Fifty women from each practice were randomly selected to take part in the study with 25 in each study group. This size of sample was chosen so that the project could be completed in a reasonable time without creating an excessive demand for smears in the practices in the short term. The first group was sent a letter inviting the patient to contact the surgery to make arrangements for a smear test (letter only group). The second group was sent one that included an appointment for a smear and asked the patient to make alternative arrangements with the surgery if it was inconvenient or if she wished to cancel for other reasons (appointment group). Both groups were asked to respond within three weeks of receiving the letter. Non-respondents in both groups were sent up to two reminders; they were similar to the first letter except that the alternative of attending a health authority clinic was mentioned.

Before the letters were sent three women left their practices, and of the 247 letters sent seven were returned as "address unknown." This reduced the number in the letter only group to 122 and that in the appointment group to 118 . Responses to the two methods of call are shown in the table. 
Attendance for smear test after initial letter and two reminders

\begin{tabular}{|c|c|c|c|}
\hline & $\begin{array}{l}\text { Letter only } \\
\text { group }\end{array}$ & $\begin{array}{l}\text { Appointment } \\
\text { group }\end{array}$ & $\begin{array}{c}\% \text { Greater response } \\
\text { shown by appoint- } \\
\text { ment group ( } 95 \% \\
\text { confidence interval) }\end{array}$ \\
\hline $\begin{array}{l}\text { No }(\%) \text { attending after } \\
\text { initial letter } \\
\text { Cumulative total }(\%) \\
\text { after first reminder } \\
\text { Cumulative total }(\%) \\
\text { after second reminder } \\
\text { Cumulative total }(\%) \\
\text { women aged } 45-54 \cdot 5 \\
\text { after second reminder } \\
\text { Cumulative total }(\%) \\
\text { women aged } 54 \cdot 5-65 \text { years } \\
\text { after second reminder }\end{array}$ & $\begin{array}{l}26 / 122(21) \\
34 / 122(28)^{\star} \\
39 / 122(32) \dagger \\
28 / 74 \quad(38) \\
11 / 48\end{array}$ & $\begin{array}{l}43 / 118(36) \\
52 / 118(44) \\
56 / 118(47)\end{array}$ & $\begin{array}{l}15(4 \text { to } 27) \\
16(4 \text { to } 28) \\
15(3 \text { to } 28) \\
10(-7 \text { to } 26)\end{array}$ \\
\hline
\end{tabular}

^Included two women who attended a health authority clinic.

t Included three women who attended a health authority clinic.

\section{Comment}

The overall response rate was lower than in other studies. ${ }^{4}$ The most likely explanation is that reluctance to attend for a smear test is greatest in women who have never had one. Our results suggest, however, that middle aged women who have not had a smear test are more likely to accept an invitation to have one if the general practitioner offers a specific appointment rather than an open invitation. This was especially true for women aged 54-65. Owing to the small number of women in this study we cannot be sure about the magnitude of this difference, but it is probably at least $6 \%$ and may be as much as $43 \%$. It has been reported that older women are less likely to attend for cervical cytology. ${ }^{3}$ We saw this in the letter only group but not in the appointment group. Sending times of appointments is administratively more complex than sending each patient an identical letter, especially if the letters of invitation are dispatched from the family practitioner committee, which was the original plan in Nottingham. Such an appointment system would allow practices to have more control over their workload, however, and if the invitations were sent directly from the general practitioner it would allow easier updating at the last minute.

This study was funded by the health promotion group of Nottingham Health Authority. Many thanks are due to those general practitioners taking part and to Nottinghamshire Family Practitioner Committee for its support.

1 ICRF Coordinating Committee on Cervical Screening. Organisation of a programme for cervical cancer screening. BrMed f 1984;289:894-5.

2 Standing $P$, Mercer S. Quinquennial cervical smears: every woman's, right and every general practitioner's responsibility. Br Med f 1984;289:883-6.

3 Wakefield J. Studies on the response to cervical screening. Tumori 1976;62:315-8.

4 Editorial Committee of the Cardiff Cytology Study. Enumeration and definitions of population and initial acceptance rates. F Epidemiol Community Health 1980;34:9-13.

(Accepted 24 April 1987)

Department of General Practice, University of Nottingham, Queen's Medica Centre, Nottingham NG7 2UH

ANDREW WILSON, MB, MRCGP, lecturer in general practice

ANNA LEEMING, MA, researcher, community unit, Nottingham Health Authority

Correspondence to: Dr Wilson.

\section{Isolated minimal change nephropathy associated with diclofenac}

Several renal changes have been associated with treatment with nonsteroidal anti-inflammatory drugs. ${ }^{12}$ We report two cases of isolated minimal change nephropathy after treatment with diclofenac.

\section{Case reports}

CASE 1

A 70 year old woman with hypertension had been taking atenolol, chlorthalidone, and hydralazine for more than a year. Three months before her admission diclofenac $100 \mathrm{mg}$ a day had been added because of coxarthrosis. Two and a half months after diclofenac was started a dipstick test for proteinuria had yielded a negative result. Two weeks later progressive peripheral oedema and anorexia developed, prompting her to stop taking diclofenac.

On admission she had massive oedema of the legs and moderate hypertension. Serum creatinine concentration was $230 \mu \mathrm{mol} / \mathrm{l}$, serum albumin concentration $13 \mathrm{~g} / \mathrm{l}$, and urinary protein excretion $14 \mathrm{~g} / 24 \mathrm{~h}$. Urine microscopy showed a few red and white cells and some hyaline and granular casts. No other cause of her nephrotic syndrome was found. Three weeks after she stopped taking diclofenac renal biopsy was performed. Appearances on light microscopy, immunofluorescence, and electron microscopy were compatible with a minimal change nephropathy. Symptomatic treatment was started, consisting of sodium restriction, frusemide, and albumin infusions (figure). After two and a half weeks indomethacin $100 \mathrm{mg}$ a day was added. Proteinuria decreased gradually and 26 days after the renal biopsy had resolved.

CASE 2

A 56 year old woman with arthritis of the knee took diclofenac $150 \mathrm{mg}$ a day for two separate periods of 13 and 20 days. After the second period she was admitted two separate periods of 13 and 20 days. After the second period she was admitted $90 \mu \mathrm{mol} / \mathrm{l}$, serum albumin concentration $18 \mathrm{~g} / \mathrm{l}$, and urinary protein excretion $11 \mathrm{~g} / 24 \mathrm{~h}$. Urine microscopy showed $15-25$ leucocytes and a few erythrocytes per field; urine culture gave negative results. Further laboratory investigations showed no cause for the nephropathy. Six weeks after she stopped taking diclofenac a renal biopsy was performed. Appearances on microscopy, immunofluorescence, and electron microscopy were compatible with a minimal change nephropathy.

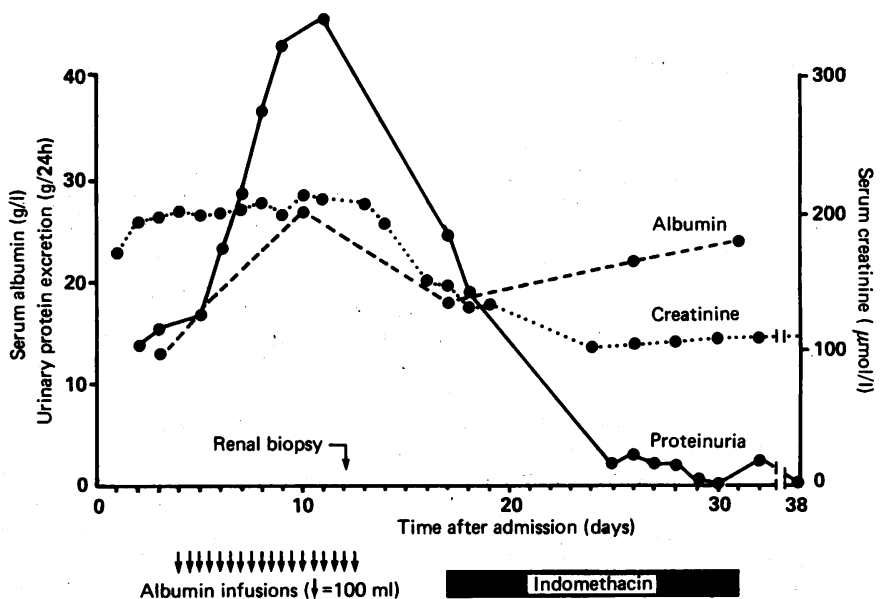

Serum creatinine and albumin concentrations and 24 hour urinary protein excretion after treatment with diclofenac.

Two weeks later she began treatment with prednisone $75 \mathrm{mg}$ a day because conservative treatment with diuretics and salt restriction had been unsuccessful, with serum albumin concentration decreasing and her renal function deteriorating. After 14 days the dose was reduced to $10 \mathrm{mg}$ a day. The proteinuria decreased gradually and was completely gone after three weeks. Proteinuria did not recur after the prednisone was stopped.

\section{Comment}

In most cases of nephrotic syndrome associated with treatment with nonsteroidal anti-inflammatory drugs interstitial nephritis is found on biopsy, although tolmetin and sulindac have been associated with isolated minimal change nephropathy. ${ }^{3}$ The clinical course in our patients suggests that diclofenac was responsible for their minimal change nephropathy. Minimal change nephropathy has been described before with diclofenac, but interstitial nephritis was also present. ${ }^{4}$ Sampling error might account for the failure to show interstitial nephritis in our patients, but as the number of glomeruli in the biopsy specimens was 10 and 15 , respectively, this was unlikely.

The pathophysiology of this adverse effect of diclofenac is unknown, but the absence of interstitial nephritis is an argument against a mechanism mediated by $T$ cells. ${ }^{5}$ The fact that the proteinuria resolved after indomethacin was added to treatment in case 1 argues against a pivotal role of inhibition of prostaglandin as well.

1 Clive DM, Stoff JS. Renal syndromes associated with nonsteroidal anti-inflammatory drugs. $N$ Engl f Med 1984;310:563-72.

2 Billings RA, Burry HC, Emslie FS, Kerr GD. Vasculitis with aclofenac therapy. $\mathrm{Br}$ Med $\mathcal{J}$ 1974;iv:263-5 